\title{
BLASTOCYST DEVELOPMENT OF MOUSE PRE-IMPLANTATION EMBRYOS IN THE RABBIT FALLOPIAN TUBE
}

\author{
R. L. BRINSTER AND JOAN THOMSON TENBROEGK \\ King Ranch Laboratory of Reproductive Physiology, School of Veterinary Medicine, \\ University of Pennsylvania, Philadelphia, U.S.A.
}

(Received 28th Fune 1968, revised 8th August 1968)

Summary. Fertilized one- and two-cell mouse embryos were transferred to the rabbit Fallopian tube. No blastocysts developed from 730 one-cell embryos transferred. A total of 141 blastocysts developed from 540 two-cell embryos transferred.

\section{INTRODUCTION}

The mouse embryo can be cultivated in vitro from the two-cell stage to the blastocyst (Brinster, 1963, 1965) and from the fertilized one-cell stage to the two-cell stage (Whittingham \& Biggers, 1967). Mouse embryos will not, however, develop in vitro from the fertilized one-cell stage to the blastocyst, but the one-cell embryo will develop into a blastocyst within the explanted Fallopian tube cultivated in vitro (Biggers, Gwatkin \& Brinster, 1962).

This information suggests that the Fallopian tube provides some environmental condition or nutrient that is not provided in the culture media which have been employed. The nature of this contribution of the Fallopian tube is not known, nor is it known whether the contribution to the embryo is the same in the mouse as in other species. If the Fallopian tube contribution is the same in different species, one-cell and/or two-cell mouse embryos should develop into blastocysts in the rabbit tube.

To determine if the rabbit Fallopian tube would allow development of the early mouse embryo, one- and two-cell mouse embryos were transferred into rabbit Fallopian tubes and their subsequent development was recorded. The results of these experiments are reported here.

\section{MATERIALS AND METHODS}

The mouse embryos used in these experiments were obtained by superovulating random-bred Swiss females 6 to 10 weeks old. The mice were superovulated by an intraperitoneal injection of 5 i.u. of pregnant mare serum gonadotrophin (Gestyl, Organon), followed 40 to $48 \mathrm{hr}$ later by 5 i.u. of human chorionic gonadotrophin (HCG) (Pregnyl, Organon). The females were placed with males at the time of the second injection, and those with vaginal plugs the following morning were used for the collection of fertilized one-cell and two-cell embryos. 
The embryos were collected by standard techniques (Brinster, 1965, 1969), and pooled before transfer into the rabbits. The cumulus cells were removed from the one-cell embryos with hyaluronidase $(150 \mathrm{i} . u . / \mathrm{ml})$ before transfer.

New Zealand White rabbits weighing 3 to $4 \mathrm{~kg}$ were used as recipients. The does were given 100 i.u. of HCG and mated on the afternoon before the mouse embryos were to be transferred. In the experiments where does in later stages of pregnancy and pseudopregnancy were used as recipients, the does were mated 8 days before transfer. All rabbits were caged individually for at least 2 weeks before the experiment and during the experiment.

For transfer, the rabbits were anaesthetized with sodium pentobarbital, and the abdomen was opened with a midline incision 6 to $8 \mathrm{~cm}$ in length. The Fallopian tubes were exposed, one at a time, and the mouse embryos, contained in approximately $10 \mu \mathrm{l}$ of culture medium (Brinster's medium for ovum culture; Brinster, 1969), were placed in the ampulla of the tube. The embryos in the medium were transferred with a finely drawn Pasteur pipette. The pipette was either inserted through the fimbrial opening of the Fallopian tube or was inserted through the wall of the tube at the first turn of the ampulla. The uterotubal junction was ligated and the reproductive organs returned to their normal position. After the abdominal incision was sutured, each animal received 100 $\mathrm{mg}$ of chloramphenicol intraperitoneally and 200,000 units of benzathine penicillin $\mathrm{G}$ intramuscularly.

When fertilized one-cell embryos were transferred, the rabbits were re-opened 5 days after transfer, at the time when the embryos would normally be blastocysts. When two-cell embryos were transferred, the rabbits were re-opened 4 days after transfer. In each case, the Fallopian tube was flushed with culture medium, and the number of mouse blastocysts present was counted.

\section{RESULTS}

In the first experiments, fertilized one-cell embryos were collected on the day when the vaginal plug was found. A total of 730 of these embryos was transferred into eleven rabbits. The results of these transfers are shown in Table 1. No blastocysts were found, and most of the mouse embryos which were recovered were degenerated. In the second group of experiments, two-cell embryos were collected and transferred. A total of 540 embryos was transferred into six rabbits. From these embryos, 141 blastocysts developed (Plate 1). The results are shown in Table 2. Again, most of the embryos which had not developed to blastocysts were degenerated or their zonae pellucidae contained only granular material.

In both types of experiment, it was noted in the first transfers that fewer embryos were recovered than were put into the Fallopian tube. In later experiments, an exact count of all embryos recovered was made on each Fallopian tube. Tables 1 and 2 show that only between one-third and one-half of the embryos which are transferred can be recovered 4 to 5 days later. Some of these 'lost' embryos may have passed out through the fimbriated end of the tube during the transfer manipulations. However, many of the embryos which do not develop, become surrounded by small cells which closely adhere to the 
PLATE 1

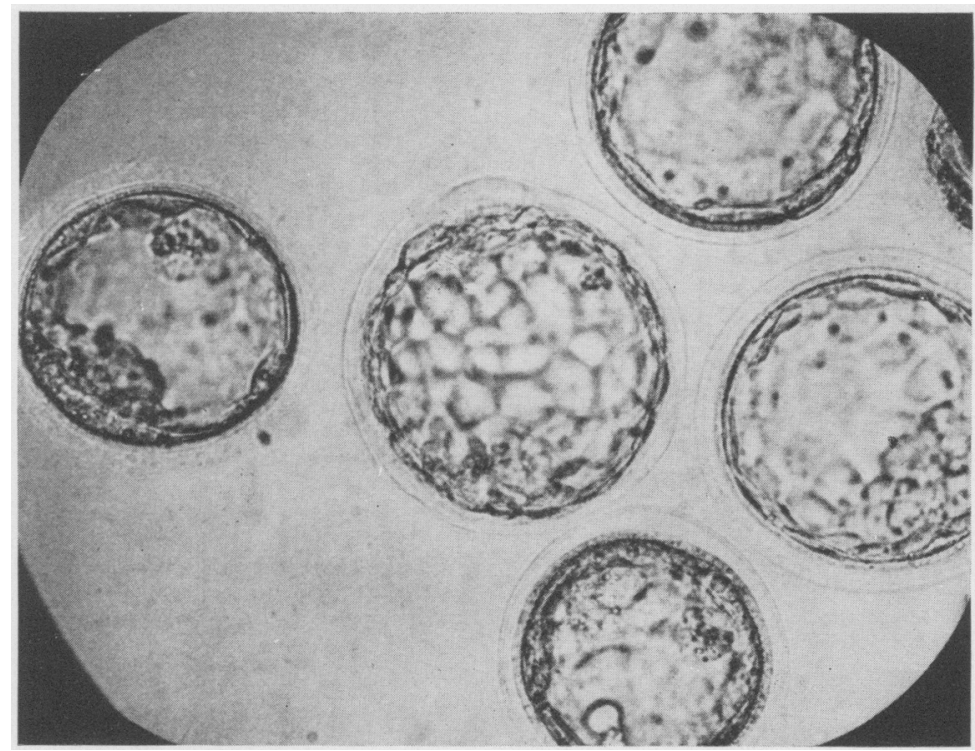

A group of five blastocysts developed from two-cell mouse embryos after 4 days in the rabbit Fallopian tube. $\times 190$.

(Facing p. 418) 
surface and make identification of the surrounded cell practically impossible. Despite the fact that all embryos are not accounted for, it seems clear from the data in Tables 1 and 2 that there is a striking difference in the ability of the rabbit Fallopian tube to support the development of one- and two-cell mouse embryos. Not a single blastocyst developed from a transferred one-cell embryo, whereas $25 \%$ of the two-cell embryos developed to blastocysts.

TABLE 1

NUMBER OF BLASTOCYSTS WHIGH DEVELOPED FROM FERTILIZED ONE-GELL MOUSE EGGS TRANSFERRED INTO RABBITS

\begin{tabular}{c|c|c|c}
\hline $\begin{array}{c}\text { Rabbit } \\
\text { no. }\end{array}$ & $\begin{array}{c}\text { Mouse } \\
\text { embryos } \\
\text { transferred }\end{array}$ & $\begin{array}{c}\text { Mouse } \\
\text { blastocysts } \\
\text { recovered }\end{array}$ & $\begin{array}{c}\text { Other mouse } \\
\text { embryos } \\
\text { recovered }\end{array}$ \\
\hline 1 & 30 & 0 & - \\
2 & 40 & 0 & - \\
3 & 40 & 0 & - \\
4 & 100 & 0 & - \\
5 & 80 & 0 & - \\
6 & 60 & 0 & 26 \\
7 & 60 & 0 & 29 \\
8 & 80 & 0 & 16 \\
9 & 80 & 0 & 4 \\
10 & 80 & 0 & 44 \\
11 & 80 & 0 & 27 \\
\hline Total & 730 & 0 & 146 \\
\hline
\end{tabular}

TABLE 2

NUMBER OF BLASTOCYSTS WHICH DEVELOPED FROM TWO-CELL EMBRYOS TRANSFERRED INTO RABBITS

\begin{tabular}{c|c|c|c}
\hline $\begin{array}{c}\text { Rabbit } \\
\text { no. }\end{array}$ & $\begin{array}{c}\text { Mouse } \\
\text { embryos } \\
\text { transferred }\end{array}$ & $\begin{array}{c}\text { Mouse } \\
\text { blastocysts } \\
\text { recovered }\end{array}$ & $\begin{array}{c}\text { Other mouse } \\
\text { embryos } \\
\text { recovered }\end{array}$ \\
\hline 1 & 70 & 22 & - \\
2 & 70 & 3 & - \\
3 & 80 & 21 & - \\
4 & 200 & 73 & 36 \\
5 & 60 & 15 & 30 \\
6 & 60 & 7 & 11 \\
\hline Total & 540 & 141 & 77 \\
\hline
\end{tabular}

If one-cell mouse embryos are allowed to cleave in vitro to the two-cell stage and then transferred to the mouse Fallopian tube, they will develop to blastocysts (Whittingham \& Biggers, 1967). A series of experiments was performed to determine if two-cell embryos produced in this manner would develop in the rabbit Fallopian tube, and the results are shown in Table 3. Of 320 embryos transferred into four rabbits, none developed into blastocysts. This suggests 
that the block to development is after the first cleavage but before the end of the two-cell stage, since two-cell embryos develop into blastocysts.

In the last group of experiments, an attempt was made to determine the effect of the hormonal state of the rabbit on the development of the two-cell mouse embryos. In these experiments the embryos were transferred into rabbits which were 8 days pregnant or 8 days pseudopregnant and had large corpora lutea. The results are shown in Table 4. A total of 340 embryos was transferred

TABLE 3

NUMBER OF BLASTOCYSTS WHIGH DEVELOPED FROM ONE-GELL EMBRYOS GROWN IN VITRO TO TWO-GELL AND THEN TRANSFERRED

\begin{tabular}{c|c|c|c}
\hline $\begin{array}{c}\text { Rabbit } \\
\text { no. }\end{array}$ & $\begin{array}{c}\text { Mouse } \\
\text { enbryos } \\
\text { transferred }\end{array}$ & $\begin{array}{c}\text { Mouse } \\
\text { blastocysts } \\
\text { recovered }\end{array}$ & $\begin{array}{c}\text { Other mouse } \\
\text { embryos } \\
\text { recovered }\end{array}$ \\
\hline 1 & 100 & 0 & 20 \\
2 & 100 & 0 & 17 \\
3 & 60 & 0 & 42 \\
4 & 60 & 0 & 18 \\
\hline Total & 320 & 0 & 97 \\
\hline
\end{tabular}

TABLE 4

NUMBER OF BLASTOCYSTS WHICH DEVELOPED FROM TWOCELL EMBRYOS TRANSFERRED INTO RABBITS 8 DAYS PREGNANT

\begin{tabular}{c|c|c|c}
\hline Rabbit no. & $\begin{array}{c}\text { Mouse } \\
\text { embryos } \\
\text { transferred }\end{array}$ & $\begin{array}{c}\text { Mouse } \\
\text { blastoysts } \\
\text { recovered }\end{array}$ & $\begin{array}{c}\text { Other mouse } \\
\text { embryos } \\
\text { recovered }\end{array}$ \\
\hline $\begin{array}{c}\text { Pregnant 1 } \\
\text { Pregnant 2 }\end{array}$ & $\begin{array}{c}\text { 800 } \\
\text { Pseudopregnant 3 }\end{array}$ & 3 & 3 \\
Pseudopregnant 4 & 80 & 5 & 22 \\
\hline Total & 80 & 30 & 13 \\
\hline & 340 & 47 & 64 \\
\hline
\end{tabular}

into four rabbits and forty-seven blastocysts were recovered. Blastocysts developed in Fallopian tubes of both pregnant and pseudopregnant rabbits suggesting that the hormonal state of the animal does not determine whether the two-cell embryo will develop into a blastocyst.

\section{DISCUSSION}

Transfer of embryos between various species has been investigated by a number of workers. For example, Warwick \& Berry (1949) examined transfers between sheep and goat, Briones \& Beatty (1954) made transfers between the mouse, rabbit, rat and guinea-pig, Averill, Adams \& Rowson (1955) transferred sheep ova to the rabbit and Chang (1966) has studied the reciprocal transplantation 
of rabbit and ferret eggs. The number of studies is much larger, but none of them has specifically investigated whether successful transfer depends on the stage at which the embryo is transferred. The results presented in this paper clearly show that the stage is important in the transfer of mouse embryos into the rabbit. This finding has the important implication that the secretions of Fallopian tubes of different species are not functionally interchangeable. At one stage of embryonic development the tubal secretions may be adequate, whereas at another stage of development the secretions may be inadequate for a particular embryo.

In the case of the mouse embryo, the ability of the rabbit Fallopian tube secretions to support development appears to be similar to the ability of culture medium to support the development. That is, both the tubal secretions and culture medium allow development from two-cell stage to blastocyst but not from one-cell stage to blastocyst. In addition, the block to further development of the one-cell embryo after the first cleavage appears to be at the same developmental stage in the studies reported here as was found by Whittingham, \& Biggers (1967) using in vitro culture techniques. The characteristic of the block is that mouse embryos appear to need an exposure to the mouse Fallopian tube immediately after the first cleavage. This suggests that the mouse Fallopian tube produces some environmental condition essential for the development of the mouse embryo, which the rabbit Fallopian tube cannot provide. The nature of this environmental condition awaits further study.

\section{ACKNOWLEDGMENTS}

Financial support for this work was from the National Institutes of Health grant HD 03071 and HD 02315. I thank. Miss Mary Ryans for her excellent technical assistance.

\section{REFERENCES}

Averill, R. L. W., Adams, C. E. \& Rowson, L. E. (1955) Transfer of mammalian ova between species. Nature, Lond. 176, 167.

Biggers, J. D., Gwatkin, R. B. L. \& Brinster, R. L. (1962) Development of mouse embryos in organ cultures of fallopian tubes on a chemically defined medium. Nature, Lond. 194, 747.

BRINSTER, R. L. (1963) A method for in vitro cultivation of mouse ova from two-cell to blastocyst. Expl Cell Res. 32, 205.

BRINSTER, R. L. (1965) Studies on the development of mouse embryos in vitro. IV. Interaction of energy sources. F. Reprod. Fert. 10, 227.

Brinster, R. L. (1969) Mammalian embryo culture. In: The Mammalian Oviduct. Eds. E. S. E. Hafez and R. Blandau. University of Chicago Press, New York.

BRiones, H. \& BEATTY, R. A. (1954) Interspecific transfers of rodent eggs. F. exp. Zool. 125, 99.

Chang, M. C. (1966) Reciprocal transplantation of eggs between rabbit and ferret. F. exp. Zool. 161, 297.

WARWICK, B. L. \& BERRY, R. O. (1949) Intergeneric and intraspecific embryo transfers in sheep and goats. F. Hered. 40, 297.

Whittingham, D. \& Biggers, J. D. (1967) Fallopian tube and early cleavage in the mouse. Nature, Lond. 213,942. 